\title{
Older Adults and the Digital Divide in Romania: Implications for the COVID-19 Pandemic
}

\author{
Loredana Ivan, $\mathrm{PhD}$
}

Communication Department, National University of Political Studies and Public Administration, Bucharest, Romania, loredana.ivan@comunicare.ro

Stephen J. Cutler, $\mathrm{PhD}^{\star}$

Professor of Sociology, Emeritus and Emeritus Bishop Robert F. Joyce

Distinguished University Professor of Gerontology, Department of Sociology, University of Vermont, Burlington, Vermont, 05405, scutler@uvm.edu

${ }^{\star}$ Stephen J. Cutler will serve as the corresponding author.

\section{Abstract}

At the beginning of the COVID-19 pandemic, Romania invoked the $15^{\text {th }}$ Amendment of the European Convention of Human Rights for emergency situations and issued an Emergency State Presidential Decree (first put into effect on March 16 and extended until May 15, 2020). This amendment allowed for exemptions from broad categories of human rights (e.g., the right to privacy and intimacy). Older people became the main target of the Romanian government's plans for isolation. Using data from the Romanian National Institute of Statistics and data gathered prior to the COVID-19 pandemic from a longitudinal study on communication technologies used by older people in Romania (Loos, Nimrod, \& Fernández-Ardèvol, 2018; 2020), we examine the digital inequalities faced by Romanian elders. The current study addresses the following specific research questions: (1) what digital opportunities and limitations were faced by the older population of Romania: e.g., online shopping, asking for help from various organizations using online platforms, using online medical assistance, etc., and (2) how did digital inequalities shape the lives of older people in Romania? Although the data do not reflect the situation of older Internet users during pandemics, we used the most recent and detailed data regarding Internet behavior of older adults in Romania. The current article discusses the opportunities faced by those who already had access and Internet skills when the pandemic started, and the limitations faced by older people who were less digitally skilled. With many of the daily activities moving online during this 
period, older adults with poor digital skills or no Internet access risked social isolation. Also, we consider policy recommendations to reduce digital inequalities that affect elders. Although we focus on Romania, the current study typifies vulnerabilities older people face in emergent economies during the COVID-19 pandemic.

Keywords: digital inequalities; digital divide; older adults; older people \& Internet use

\section{Adultos mayores y la brecha digital en Rumania: implicaciones para la pandemia COVID-19}

\section{RESUMEN}

Al comienzo de la pandemia de COVID-19, Rumania invocó la 15a Enmienda del Convenio Europeo de Derechos Humanos para situaciones de emergencia y emitió un Decreto Presidencial del Estado de Emergencia (que entró en vigencia por primera vez el 16 de marzo y se extendió hasta el 15 de mayo de 2020). Esta enmienda permitió exenciones de categorías amplias de derechos humanos (por ejemplo, el derecho a la privacidad y la intimidad). Las personas mayores se convirtieron en el principal objetivo de los planes de aislamiento del gobierno rumano. Utilizando datos del Instituto Nacional de Estadística de Rumanía y datos recopilados antes de la pandemia COVID-19 de un estudio longitudinal sobre tecnologías de comunicación utilizadas por personas mayores en Rumanía (Loos, Nimrod y Fernández-Ardèvol, 2018; 2020), examinamos el Desigualdades digitales a las que se enfrentan los ancianos rumanos. El estudio actual aborda las siguientes preguntas de investigación específicas: (1) qué oportunidades y limitaciones digitales enfrentaron la población mayor de Rumania: por ejemplo, compras en línea, pedir ayuda a varias organizaciones que utilizan plataformas en línea, usar asistencia médica en línea, etc. y (2) ¿cómo influyeron las desigualdades digitales en la vida de las personas mayores en Rumanía? Aunque los datos no reflejan la situación de los usuarios mayores de Internet durante las pandemias, utilizamos los datos más recientes y detallados sobre el comportamiento de los adultos mayores en Internet en Rumanía. El artículo actual analiza las oportunidades que enfrentan quienes ya tenían acceso y habilidades de Internet cuando comenzó la pandemia, y las limitaciones que enfrentan las personas mayores que tenían menos habilidades digitales. Con muchas de las actividades diarias 
moviéndose en línea durante este período, los adultos mayores con habilidades digitales deficientes o sin acceso a Internet corrieron el riesgo de aislamiento social. Además, consideramos recomendaciones de políticas para reducir las desigualdades digitales que afectan a las personas mayores. Aunque nos centramos en Rumania, el estudio actual tipifica las vulnerabilidades que enfrentan las personas mayores en las economías emergentes durante la pandemia de COVID-19.

Palabras clave: desigualdades digitales; divisoria digital; adultos mayores; personas mayores y uso de Internet

\section{罗马尼亚的老年人和数字鸿沟: \\ 对2019冠状病毒病大流行产生的意义}

摘要

2019冠状病毒病（COVID-19）之初, 罗马尼亚援引了针对紧 急情况的《欧洲人权公约第15条修正案》，并发布了 “紧急 状态总统法令”（该法令生效于2020年3月16日并延长至同 年5月 15 日）。该修正案允许免除广泛的人权类型（例如隐 私权和亲密权）。老年人成为了罗马尼亚政府隔离计划的主 要目标。通过使用罗马尼亚国家统计局数据和COVID-19大流 行前一项关于罗马尼亚老年人使用的传播技术的纵向研究所 收集的数据 (Loos, Nimrod, \& Fernández-Ardèvol, 2018; 2020），我们分析了罗马尼亚老年人面临的数字不平等。本 研究应对了下列具体的研究问题：（1）罗马尼亚老年人口 面临哪些数字机遇和限制：例如网购、使用网络平台向不同 组织寻求帮助、使用网络医疗协助等; (2) 数字不平等如 何影响了罗马尼亚老年人的生活？尽管数据并不反映大流行 时期老年网络用户的情况, 但我们就罗马尼亚老年人的互联 网行为使用了最新且最详细的数据。本文探讨了那些在大流 行开始时已经具备互联网获取及技能的人士所面临的机遇, 以及那些数字技能欠佳的老年人所面对的限制。随着许多每 日活动在这段时期进入网络, 数字技能欠佳或无法获取互联 网的老年人面临社交孤立的风险。我们还考量了政策建议, 以期减少影响老年人的数字不平等。尽管我们聚焦于罗马尼 亚, 但本研究反映了COVID-19大流行期间老年人在新兴经济 体中面临的典型脆弱性。

关键词: 数字不平等, 数字鸿沟, 老年人, 老年人与互联网 使用 


\section{The digital divide and vulnerabilities of older people during the time of COVID-19}

7 he digital divide refers to inequalities between people from 1 different social groups (based on age, gender, ethnicity, etc.) in the way they access new digital technologies. The digital divide describes an information or knowledge gap and a computer or media literacy gap between different groups of people, and it is explained by structural and motivational factors (Van Dijk, 2006). Van Dijk (2003) draws our attention to the fact that the digital divide refers to relative inequalities between social groups and not absolute inequalities, meaning that some "gaps" are diminished with the pervasiveness of the information and communication technologies and inequalities are being reduced, whereas other gaps are more difficult to bridge, as they incorporate more complex factors. For example, the gaps between generations in accessing the new media might be a natural phenomenon in which each generation would prefer the use of media they were familiar with in their formative years (Loos, Ivan, \& Bird, 2020; Sackmann \& Winkler, 2013). Therefore, we agree with Van Dijk (2006, p. 222) that the "digital divide" is a metaphor-defining a dynamic phenomenon in which some social groups might be left behind in receiving some of the benefits associated with the use of Internet. Nevertheless, the idea of the "digital divide" is rather normative and suggests the fact that the use of the new technologies is per se good and it brings only positive aspects to people's lives.

Regardless of the negative issues discussed in the literature on the overuse of the Internet (for example: online-scamming and fraud [Shao et al., 2019; Whitty, 2018]; online bullying [Juvonen \& Gross, 2008]; the risk of over exposure to fake news [Brashier \& Schacter, 2020; Loos, Ivan, \& Leu, 2018]), some groups, including older people, are consistently perceived as "laggards," and they are encouraged to use more of the new technologies. In some ways, the literature on the negative effects of the use of digital media focuses on youth, whereas for seniors the focus is on the positive aspects. Although we cannot say that using the Internet is always a sign of emancipation and progress, and it implicitly generates well-being in people's lives, there are some contexts in which digital gaps create serious inequalities. The recent situation of the COVID-19 pandemic is a typical case in which the digital divide directly affected people's lives: they were forced to stay in their homes for a long period of time, and everyday activities such as shopping and the use of medical services were moved as much as possible online. Hence, the most vulnerable groups, the ones described by Prensky (2001) as "digital immigrants" (a term criticized in the literature for over-homogenization [see Jones, 2010; Lenhart \& Horrigan, 2003; Loos, 2012 - they talk about a digital spectrum not a digital dichotomy]) were the most affected by the lockdown.

Older people (60 years and above) 
were and still are a group facing numerous difficulties during the COVID-19 pandemic. On the one hand, they were described as a population category at high risk of mortality ( $94 \%$ of fatalities are concentrated in the population over 60 years of age, according to European Commission estimates [May, 2020]). In some countries, the lockdown conditions were stricter for the group 60 years of age or 65 years and older because they were considered to be at higher risk. Children and grandchildren were advised to limit their visits to grandparents to avoid exposing them to the virus. In Romania, for example, the restrictions were stricter for people 65 years and older during the lockdown; they were advised to leave their houses only during designated hours. In many countries, people were reminded that "we should limit our interactions" and be "precautious" with older people in our families and with neighbors and co-workers who may be older.

There is a general understanding that older people are the most affected by the digital divide phenomenon. For example, the term launched by Prensky (2001) — "digital immigrants" -described the presumed digital gap between older and younger peoplethe latter the so-called "digital natives" (the group that was born when the new technologies were largely available). Consequently, the lockdown situation and the subsequent measures of social isolation would have affected older people to a larger extent, as they lagged in using Internet-based tools.

Generally speaking, the digital divide is "a division between people who have access and use of digital media and those who do not" (Van Dijk, 2020, p. 1). There are different types of digital divide (see Van Dijk \& Hacke, 2003; Van Dijk, 2005; 2012) generated by differences in motivation, physical access, digital skills, and use of the new technologies. Those types of digital gaps have had different dynamics over the past 15 years and have generated different degrees of unequal participation in societies. Van Dijk (2012; 2020) stated that there has been a shift from motivation and access to inequalities in skills and different usage. In other words, people's motivation and physical access to digital technologies is a bridge that "has been crossed" in many societies, including developing countries, whereas other bridges are more difficult to cross: for example, older people still are behind in skills and usage opportunities-a situation that will probably be maintained in the future.

The evolution of the digital divide at the level of the general population over the past 15 years explains the current situation of older people and how digital inequities could have shaped their lives during the lockdown. The first level of the digital divide (1995 - 2004) has been described as a gap in the adoption of computer and Internet connections between different social groups. During this period of time, the adoption rate increased exponentially and the "divide" between people along the lines of education, income, ethnicity, and age decreased both in Europe and in the U.S. (Eurostat, 2019; Pew Research Center, 2019a). At the same time, the general attitude toward Inter- 
net use and digital technologies became positive: people of different ages and socio-economic backgrounds were motivated to learn to use computer-based technologies and to benefit from using the Internet.

The divide continued to be an issue for social groups that could not afford computers and Internet access or those without Internet access. The issue of costs for some social groups, such as retirees and older people in nursing homes, is still a problem not only in developing countries (see studies conducted in Latin America regarding digital technology, affordability, and costs: Barrantes, 2007; Barrantes \& Matos, 2020). Costs and affordability continue to be a barrier also in some developed countries (see for example Sawchuk, Joy, \& Hebblethwaite, 2019). Although the number of broadband subscriptions has grown significantly in practically every country, depopulated rural or remote areas are difficult to reach. In Eastern European countries, for example, strongly affected by migration for work, older people were the ones left behind. Many rural localities face a demographic decline, and an increased number in the oldest-old population who neither have the resources to purchase digital technologies nor the skills to benefit from Internet opportunities. For such groups of people, the COVID-19 pandemic would have probably increased their isolation or brought no changes at all. To quote from an interview conducted in April 2020 with a person from a remote rural area in Romania (Ivan \& Mandache, submitted): "they [the village hall] wanted to isolate us in houses, but we are already isolated." Many of these people have the motivation to learn to use the new digital devices (sometimes the Internet is the only way to communicate with families abroad: see for example Ducu, 2020; Ivan \& Fernández-Ardèvol, 2017), but they lack the opportunities.

The second level of the digital divide (2004-present), which describes differences between usage and skills, is a way of "rethinking the digital divide" (Hargittai, 2002; Selwyn, 2004; Van Dijk, 2012). With the pervasiveness of the Internet and digital technologies (for example, in ten years' time, 2004-2014, Internet users around the globe increased from $15 \%$ to $45 \%$ and it reached $53.6 \%$ in 2019, according to the International Communication Union 2019) the problem of access became rather peripheral. Also, the groups previously considered as "vulnerable" were the ones that recorded the highest increases of Internet users: women, seniors, persons with lower levels of education, and people who have lower incomes. To provide an illustration, the percentage of people 65 years and above who use the Internet has tripled during 2004-2019, from 20\% to more than 60\% (Eurostat, 2019; Pew Research Center, 2019b), the largest increase compared to other age groups. With many countries reaching $90 \%$ of the population having Internet access (even in developing countries, the percentage is above 60), the emphasis has moved to the gap between different groups in digital skills and the type of usage. In order to benefit from the Internet-based technologies, people need "digital literacies" (Hargittai, 2002; Van 
Deursen \& Van Dijk, 2010). The usage gaps create gaps in knowledge and opportunities, and the vulnerable groups are the later adopters: people who are older, have lower levels of education, have lower income, and are members of minority groups.

It is obvious that usage gaps are much more difficult to bridge. In the past seven years, authors (Morales, Albero, \& Molina, 2010; Van Deursen \& Van Dijk, 2014) have drawn our attention to the third level of the digital divide-a gap that reproduces classic social inequalities (e.g., between rich and poor, majority and minorities, old and young) - and describes the supremacy of the groups who hold digital skills at a level that allows them to convert those skills in all political, social, cultural, educational domains. The third level of digital divide shows that it is those with higher levels of education, those who already have good jobs, and the young who will benefit more from the use of the Internet than will those who have lower levels of education, those who populate the lower classes, and older persons. Thus, the lack of digital skills reinforces an existing structure of social stratification. It is no longer a matter of access, affordability, and availability, but a matter of the relevance and readiness when using the Internet (Van Dijk, 2020). Examples of how people convert access to and skills in using digital technologies would be the ability to find better products and services at lower prices, more information regarding health issues, the ability to distinguish between reliable and non-reliable information, more chances to get a job, or even better chances to find new friends and a romantic partner.

The COVID-19 pandemic could be seen as a typical case in which the relevance of and readiness to use the Internet is particularly important. The second and third levels of the digital divide became essential, as people were forced to make use of their digital skills. Again, older people were most probably a more vulnerable group. Globally, policy makers try to estimate the percentage of people who are at risk of being laggards due to the second and the third level of the digital divide in order to create a more inclusive Internet. According to Van Dijk (2020), the estimation of the "digitally excluded" varies between $10 \%$ and $20 \%$ in developed countries, whereas in the developing countries, it is significantly higher-from $50 \%$ to $90 \%$-creating serious concerns about how the digital divide deepens already existing social inequalities.

The vulnerability of older people to the second and third levels of the digital divide is worthy of study also because countries face an accelerating increase in older population. For example, in the European Union, the population over 60 years of age is estimated to double by 2050 . The COVID-19 pandemic created an unexpected pressure to move many activities online. Though governments had to face serious challenges with "restarting" the economy in the new situation, preserving people's working places to avoid an increase in unemployment, and reinventing the delivery of education, they have generally overlooked the importance of the dig- 
ital divide in the current situation and how this might affect the lives of older people.

\section{Current study}

T $\mathrm{n}$ the current study, we explore the digital divide of older people from Romania, and we discuss the implications of digital inequalities for the context of the COVID-19 pandemic. We aim to answer the following questions:

1. What digital opportunities and limitations could be faced by the older population of Romania when daily life activities move online: e.g., online shopping, asking for help from various organizations using online platforms; using online medical assistance, etc.?

2. How did digital inequalities shape the lives of older people in Romania?

We use data gathered prior to the COVID-19 pandemic from a longitudinal study on communication technologies of older people (the ACT cross-national, longitudinal study, Loos, Nimrod, \& Fernández-Ardèvol, 2018 ; 2020) and, for comparative purposes, data from the Romanian National Institute of Statistics regarding the total population of older adults.

The ACT cross-national longitudinal study is, to our knowledge, the only longitudinal and cross-national study targeting older adults and their use of new media. In Romania, it is the first study investigating media use of older adults (60 years and above) using a nationally representative sample. The ACT cross-national, longitudinal study gathers panel data in three waves (2016, 2018, and 2020). It involves teams from Austria, Canada, Denmark, Israel, Netherlands, Romania, and Spain. The aim of the project is to explore possible processes of displacement of traditional dominant media by innovative communication practices among older people. In the current study, we use data from two waves $(2016,2018)$, and we focus on the Romanian case. The two waves were conducted by telephone with non-institutionalized Internet users aged 60 years and older. Data were collected by local commercial firms between November and December 2016 for the first wave, and in November 2018 for the second wave. The sample consisted of 800 participants for the first wave and 608 participants for the second wave.

The questionnaire included mainly closed-ended questions exploring media use, places of media use, media preferences, background characteristics, and subjective well-being (Nimrod, 2017). Translation into Romanian was undertaken by one of the co-authors of the current article. To validate the translation, a native English-speaking person re-translated it into English.

The sample in Romania was over-represented by people with medium to high levels of education, with medium or high economic status, and persons living in urban settings. As the 
sample consisted of Internet users selected using a CATI technique among the population of older people $(60+)$, we believe that such over-representation is due to the fact that older Internet users tend to be persons with medium to high levels of socio-economic status and persons who live in urban areas. Data regarding Internet users of this age group provided by the National Institute of Statistics indicated that this might be a possible explanation for the over-representation of some socio-demographic groups in our sample.

In the following, we will present the relevance of the case and aspects regarding the regulations during lockdown which directly affected older people. Then, we will present data regarding older people and digital media use in Romania, exploring the first, second, and third levels of the digital divide.

\section{The Relevance of the Case and the Context}

$\mathrm{R}$ omania is a typical example of a developing country with older ogy adopters. A cluster analysis of the Eurostat data on technology adoption at the country level (Fernández-Ardèvol, 2011) found that Romania was placed in the last cluster ( $4^{\text {th }}$ cluster) when mobile phone adoption by older people was considered, together with five other countries (Bulgaria, Croatia, the former Yugoslav Republic of Macedonia, Greece, and Poland). This particular cluster gathers countries where the adoption of mobile telephony by older persons was below the EU average. Specifically, Romania had $62.5 \%$ users in the 55-64 cohort but only $35 \%$ in the $65-$ 74 cohorts. Such a gap between ICT use by older adults in Romania and the EU average is maintained today and could be found not only in the adoption of the mobile phone, but also in digital technologies in general. Data from Eurostat (2019) show that $82 \%$ were Internet users in the 55-64 cohorts at the EU level as compared with $68 \%$ of users in Romania in the same cohort. In the 65-74 cohort $63 \%$ were Internet users at the EU level compared with $40 \%$ users in Romania for the same age cohort. During the period 2011-2019, the digital gap in terms of access and frequency of use has continuously diminished between EU countries and Romania among younger age cohorts to less than a $5 \%$ difference, but it remained at approximately $15 \%$ for the 55-64 cohort and approximately $20 \%$ for the 65-74 cohort.

Some authors (Bunker-Hellmich, 2015) speak about three categories of older adults within the third age: the "young old" (65-74), the "old" (74-84), and the "oldest-old" (85+). However, when it comes to Internet users, we lack data on people 85 years and above, and such a limitation does not apply only to Romania. The issue has been criticized already in the literature as a serious limitation when studying the Internet behavior of older adults. As we emphasized above, some of the important bodies which gather data about Internet access and use (e.g., Eurostat) present data on the category 55-64 year of age. In the ACT longitudinal study, we compared persons 60 to 64 years of 
age (i.e., those who are still in the labor market) with those $65+$ (those who were most probably retired, as the mandatory retirement age is 65 in many EU countries, including Romania).

Romania is also a critical case when talking about the demographic predictions for 2050-2060 and for the evolution of the older population. UN (2019) estimates show that the percentage of persons above 60 years of age will be the highest in Eastern European countries. Romania will also have the highest median age of any European country and the population over 80 years of age will triple in Romania by 2050. Additionally, a large percentage of the older population currently lives in rural areas of Romania: more than $20 \%$ of the total population of Romania is currently 60 years and approximately and approximately $48 \%$ of them live in rural areas (INS, 2017).

Since the Emergency State Presidential Decree was first put into effect in Romania on March 16, 2020 (and subsequently extended until May 15, 2020), there have been several Military Decrees issued. These Military Decrees have addressed various restrictions (largely related to mobility) on the general population and on specific population categories, mainly older persons. Romania invoked the $15^{\text {th }}$ Amendment of the European Convention of Human Rights for emergency situations such as the COVID-19 pandemic. This amendment allows for exemptions from broad categories of human rights (e.g., the right to privacy and intimacy). Older people became the main target of the
Romanian government's plans for isolation. At the beginning, elders were not allowed to leave their houses; then they were allowed to go out exclusively to shop for food and medicine, but only for two hours per day; finally, there was an extension of the time period they could shop for basic goods.

\section{Opportunities and limitations for digital media use by older people}

\section{First level of the digital divide: access and use}

In 2016, when the ACT project started, official statistics (INS, 2016) showed that $60 \%$ of the 16 to 74 years of age population were Internet users in Romania, whereas the EU mean was $82 \%$ for the same year. Data regarding the older population and the use of Internet were scarce. There were estimates that between $25 \%$ and $30 \%$ of the people 60 years and over would have used the Internet in Romania. The difficulty in estimating the number of Internet users 60 years and older came from the way data were recorded: either there were data regarding the population 55 to 74 years of age or from 65 to 74 years of age. Moreover, data on people above 74 years of age were and still are scarce. All data indicated a gap of $15 \%$ to $20 \%$ between the whole population of Internet users in Romania and older users. This gap was maintained into 2018, when the percent of Romanian Internet users increased by $11 \%$, one of the largest increases among the countries in the European Union.

Table 1 shows the distribution of 
Table 1. Older Internet users by age group and gender (ACT project wave 1/2016; wave 2/2018), compare with the total population of older adults in Romania (\%)

\begin{tabular}{|c|c|c|c|c|c|c|c|c|c|}
\hline \multirow{2}{*}{$\begin{array}{l}\text { Age } \\
\text { group }\end{array}$} & \multicolumn{2}{|c|}{ Women, ACT study } & \multicolumn{2}{|c|}{ Men, ACT study } & \multicolumn{2}{|c|}{ Total, ACT study } & \multicolumn{3}{|c|}{$\begin{array}{c}\text { Total population } 60+(\text { INS, } \\
2018)\end{array}$} \\
\hline & Wave 1 & Wave 2 & Wave 1 & Wave 2 & Wave 1 & Wave 2 & Woman & Men & Total \\
\hline $60-69$ & 41.9 & 36.7 & 39.1 & 35.2 & 81.0 & 54.6 & 25.5 & 25.1 & 51.3 \\
\hline $70-79$ & 7.1 & 11.0 & 7.6 & 11.2 & 14.8 & 40.9 & 15.5 & 14.2 & 30.3 \\
\hline $80+$ & 1.7 & 2.5 & 2.6 & 3.4 & 4.3 & 4.5 & 11.0 & 8.7 & 18.4 \\
\hline Total & 50.7 & 50.2 & 49.3 & 49.8 & 100 & 100 & 52 & 48 & 100 \\
\hline
\end{tabular}

Note: $\mathrm{N}$ wave 1 (November- December 2016) $=800 ; \mathrm{N}$ wave $2($ November 2018) $=608$. The population of people over 60 in Romania (January 2018$)=5.6$ million $(25.4 \%$ of the total population)

older Internet users in December 2016 by age and gender (wave 1) and follows this sample two years later in 2018 (wave 2). These data show evidence of the dynamics of the first level of the digital divide (access and use), and the way this gap is bridged by the natural process of aging: younger people are aging, and they would then fill the gap between digital users and non-users. Also, when moving from the first wave to the second wave, Internet use has changed for the older adults in the ACT longitudinal study (Table 2). The online behavior of older adults has slightly changed between the two waves. The most prominent uses of the Internet, consistently between waves, are getting news, writing email, using social media and chat programs, and accessing websites related to one's hobbies. Duration of use for each listed activity, however, decreased between waves. Therefore, the assumption is that more study participants are engaging in more diverse activities on the Internet, but spending less time doing so. The was an increase in the reported rates of use of all type of Internet activities, most visibly in the case of using chat programs and websites that concern one's hobbies. Presumably, such a dynamic has continued in 2019 through the current time and created some opportunities for online activities of older adults using the Internet, as opposed to non-users.

The data raise some important questions about the way the first digital gap could be reduced for the oldestold population. In the context of the COVID pandemic, people 80 years of age and older would have faced serious difficulties in handling the lockdown in their homes, as only a small percentage of them used the Internet (see Table 1). Note that for this age category, women may face particular vulnerabilities as they outnumber men (the difference in life expectancy in Romania between women and men is 6 years [INS, 2017]), and they use the Internet to a lesser extent. 
Table 2. The use of Internet by older adults from the ACT longitudinal study (Wave 1/2016 versus Wave 2/2018)

\begin{tabular}{|c|c|c|c|c|}
\hline \multirow[t]{2}{*}{ Activity } & \multicolumn{2}{|c|}{ Total (\%) } & \multicolumn{2}{|c|}{$\begin{array}{l}\text { Time spent } \\
\text { (hh:mm) }\end{array}$} \\
\hline & Wave 1 & Wave 2 & Wave 1 & Wave 2 \\
\hline Getting news & 30.8 & 41.0 & $0: 49$ & $0: 44$ \\
\hline Writing and reading e-mails & 31.4 & 36.0 & $0: 27$ & $0: 22$ \\
\hline $\begin{array}{l}\text { Downloading music, films, or } \\
\text { podcasts }\end{array}$ & 5.4 & 6.4 & $0: 54$ & $0: 32$ \\
\hline Playing computer games online & 14.1 & 12.7 & $1: 12$ & 1:02 \\
\hline $\begin{array}{l}\text { Using social network sites (Face- } \\
\text { book, LinkedIn) }\end{array}$ & 33.8 & 33.7 & 1:09 & $0: 44$ \\
\hline $\begin{array}{l}\text { Using chat programs (Skype, } \\
\text { WhatsApp) }\end{array}$ & 16.4 & 24.0 & $0: 33$ & $0: 28$ \\
\hline $\begin{array}{l}\text { Reading entries at debate sites, } \\
\text { blogs }\end{array}$ & 13.0 & 13.7 & $0: 41$ & $0: 25$ \\
\hline $\begin{array}{l}\text { Writing entries at debate sites, } \\
\text { blogs }\end{array}$ & 5.3 & 7.2 & $0: 31$ & $0: 19$ \\
\hline $\begin{array}{l}\text { Online shopping, banking, travel } \\
\text { reservations }\end{array}$ & 2.4 & 4.8 & $0: 30$ & $0: 15$ \\
\hline $\begin{array}{l}\text { Using websites concerning my } \\
\text { interests or hobbies }\end{array}$ & 23.1 & 29.9 & $0: 44$ & $0: 24$ \\
\hline
\end{tabular}

Note. N (Waves 1 and 2): 608. Average time excluding outliers, calculated for those who used the medium the previous day

When comparing the structure of the ACT longitudinal survey sample and the total population of older adults on other variables (level of education, income, and residential area), we find new evidence for the first level of the digital divide among older adults (Table 3). We use data from the second wave because it is a panel sample and the differences in the respondents' educational, income, and residential status from the first wave (2016) to the second wave (2018) were small. The data show that the older Internet users are more educated than the general older population: the percentage of older Internet users having a tertiary (i.e., graduated from college) education was $44.6 \%$, whereas at the general level only $8.3 \%$ of the total population of older adults had tertiary education. The same pattern is found when we look at income and residential area of older Internet users versus the general older population: older Internet users tend to be found more in the "above the average" income category $(20.4 \%$ compared with only $9.1 \%$ in the general older population), and the majority of them live in urban settings (only $16 \%$ of older Internet users living in rural areas, whereas $48.2 \%$ of the total population 60 years and above resides in rural settings). 
Table 3. Older Internet users by level of education, income, and residential area (ACT wave $2 / 2018$ ), compared with the total population of older adults in Romania (\%)

\begin{tabular}{|c|c|c|}
\hline Education level $^{\text {a }}$ & $\begin{array}{l}\text { ACT study, } \\
\text { wave } 2 / 2018\end{array}$ & $\begin{array}{l}\text { Total popula- } \\
\text { tion } 60+ \\
(\text { INS, 2018) }\end{array}$ \\
\hline Primary or less (up to 8-9 years of education) & 6.9 & 35.9 \\
\hline Secondary (between 10 and 14 years of education) & 47.0 & 55.8 \\
\hline Tertiary ( 15 years of education or more) & 44.6 & 8.3 \\
\hline \multicolumn{3}{|l|}{ Income level $^{\text {b }}$} \\
\hline Above the average (A lot above + Slightly above) & 20.4 & 9.1 \\
\hline Similar to the average & 11.3 & ${ }^{b} 23.2$ \\
\hline Below the average (A lot below + Slightly below) & 59.9 & ${ }^{\mathrm{c}} 67.7$ \\
\hline \multicolumn{3}{|l|}{ Residency area } \\
\hline Urban & 81.4 & 51.7 \\
\hline Urban - a big city and suburbs & 43.9 & \\
\hline Urban a town or a small city & 37.5 & \\
\hline $\begin{array}{l}\text { Rural -a country village, a farm, a house in the } \\
\text { countryside }\end{array}$ & 16.0 & 48.2 \\
\hline
\end{tabular}

a The only available data on the level of education at the national level were for the population 55 to 74 years of age and we include these data in the table

b $70 \%$ of median equivalized income (adjusted for household size and composition) has been used to estimate the average income

In the case of older people, the first level of the digital divide replicates classic inequalities, maybe to a greater extent than in the case of other age categories. Internet users compared to non-users are more educated, more economically resourceful, and they live more often in urban settings. In other words, the digital vulnerabilities of the two groups (users and non-users) in the time of the COVID-19 pandemic and lockdown might have been different and corresponded to the differences between the socio-economic status of the older adults with those having low- er socio-economic status being more at risk of being excluded from the benefits of Internet use.

\section{Second and third levels of the digital divide: converting skills to outcomes}

In the longitudinal study, older Internet users had to choose, in both waves, among 20 different functions they normally use on their mobile phone (as the majority of them had a mobile phone and this was the most commonly used communication technology device). Al- 
though such an approach assesses digital skills only at the general level, it has been previously used in comparative cross-national research (for example by Eurostat, 2019). The results showed that older people from Romania who were using the Internet in 2016 did not diversify their digital skills (as measured by the number of applications they used on their mobile phone) between 2016 and 2018. We conclude that the dynamics of crossing the digital gap in terms of skills is much slower. However, some changes have been recorded in the use of the mobile phone functions: the percentage of users using phones to take photos has nearly doubled from 2016 to 2018 (from $26.8 \%$ of the total respondents in 2016 to $46.7 \%$ in 2018). Also, between the two waves, the percentage of users sending SMSs has more than tripled (from $20.3 \%$ of the total respondents in 2016 to $66.9 \%$ in 2018). Presumably in the process of learning new digital technologies acquiring new skills, some Internet based applications are more appealing to older people than others.

In the ACT longitudinal study, older adults were asked to describe the type of media they use by presenting situations that might be common in everyday life, such as notifying an ac- quaintance about changes to a party or a dinner to asking for help when sick with the flu. Here, we consider that such questions could be indicators of the way people convert skills to outputs. We select three such situations-retrieving factual information about an issue, helping with home chores, and asking for help when sick with the flu-which could be relevant in the context of the COVID pandemic and lockdown. Data are presented in Tables 4-6.

When analyzing the situation in which someone needs "to retrieve factual information about an issue" (Table 4), the data show a shift from "calling somebody" (a decrease from $45.2 \%$ to $30.9 \%$ between the two waves) to "look it up via Google" (100\% of the respondents chose this option in 2018 compared to $45.6 \%$ in 2016). Interesting also is the finding that older people did not use social network sites (the percentages of those who chose this option decreased from $5 \%$ to $1.5 \%$ from 2016 to 2018). There is evidence that people have managed to improve their abilities to convert their digital skills to outcomes in different situations. Also, when converting digital skills to outcomes, there might be preferences for the use of different media that could be specific for this age group. 
Table 4. Most likely actions taken to retrieve factual information about an issue ${ }^{\mathrm{a}}(\%)-$ ACT longitudinal study

\begin{tabular}{|l|c|c|}
\hline \multirow{2}{*}{ Actions $^{\mathbf{b}}$} & \multicolumn{2}{|c|}{$\begin{array}{c}\text { Retrieving factual } \\
\text { information }\end{array}$} \\
\cline { 2 - 3 } & Wave 1 & Wave 2 \\
\hline $\begin{array}{l}\text { Send text, voice or video message via mobile phone to someone } \\
\text { who is likely to have this information }\end{array}$ & 6.7 & 3.5 \\
\hline Call someone who is likely to have this information & 45.2 & 30.9 \\
\hline Send an email to someone who is likely to have this information & 2.1 & 1.0 \\
\hline Use social network sites (Facebook, LinkedIn) & 4.9 & 1.5 \\
\hline Use a computer-based chat program (Skype) & 1.6 & 0.0 \\
\hline Look it up in a printed encyclopedia & 9.7 & 6.6 \\
\hline Look it up via Google or other search engines & 45.6 & 100 \\
\hline Look it up at a specific website (Wikipedia) & 15.1 & 7.2 \\
\hline Don't know & 10.4 & 3.6 \\
\hline
\end{tabular}

Note. $\mathrm{N}$ (Waves 1 and 2$)=608 .{ }^{a}$ Respondents had to select three options. ${ }^{\mathrm{b}}$ Non-exclusive categories.

Table 5. Most likely actions taken to ask for help with home chores ${ }^{a}(\%)$ - ACT longitudinal study

\begin{tabular}{lc}
\hline Actions ${ }^{\mathrm{b}}$ & $\begin{array}{c}\text { Asking for help } \\
\text { with home } \\
\text { chores }\end{array}$ \\
\cline { 2 - 2 } $\begin{array}{l}\text { Send text, voice or video message via mobile phone to someone } \\
\text { who is likely to give help }\end{array}$ & 3.1 \\
Call someone who is likely to give help & 67.8 \\
Send an email to someone who is likely to give help & 0.5 \\
Use a computer-based chat program (Skype) & 0.3 \\
Meet someone who is likely to give help & 15.1 \\
Use social network sites (Facebook) & 0.2 \\
Check websites & 5.6 \\
Other & 11.3 \\
Don't know & 6.4 \\
\hline
\end{tabular}

Note. $\mathrm{N}$ (Waves 1 and 2) $=608 .{ }^{\mathrm{a}}$ Respondents had to select three options. ${ }^{\mathrm{b}}$ Non-exclusive categories. ${ }^{\mathrm{c}}$ Question not asked in Wave 1. 
Table 6. Most likely actions taken to ask for help when sick with the flu ${ }^{a}(\%)$ - ACT longitudinal study

\begin{tabular}{lc}
\hline & $\begin{array}{c}\text { Asking for help } \\
\text { when sick with } \\
\text { the flu }\end{array}$ \\
\cline { 2 - 2 } $\begin{array}{l}\text { Send messages (text or video) via mobile phone to } \\
\text { friends or family }\end{array}$ & 5.6 \\
Call friends or family on the phone & $\begin{array}{c}\text { Wave } \\
\text { Chat online via a computer with friends or family } \\
\text { (Skype) }\end{array}$ \\
Write emails to friends or family & 0.3 \\
Meet friends or family & 0.2 \\
Use social network sites (Facebook) & 3.9 \\
Other & 0.0 \\
Don't know & 12.2 \\
\hline
\end{tabular}

Note. $\mathrm{N}$ (Waves 1 and 2$)=608 .{ }^{\mathrm{a}}$ Respondents had to select three options. ${ }^{\mathrm{b}}$ Non-exclusive categories. ${ }^{\mathrm{c}}$ Question not asked in Wave 1

The question regarding "asking for help with home chores" (see Table 5) appeared only in the second wave in the ACT study. Still, the findings are particularly relevant for understanding how older Internet users from Romania proceeded with doing home chores during the lockdown. We notice the fact that almost $68 \%$ will "call somebody who is likely to give help." A relatively small percentage of people (5.6\%) would have used websites asking for help with the home chores, whereas $15 \%$ would meet someone for the same reason. The same pattern appears when people had to choose which media to use to "ask for help when sick with the flu." This situation was also not mentioned in the first wave, but it is relevant when talking about the COVID pandemic. Again, most of the older Internet users (71.7\%) would choose to "call friends of family on the phone," whereas sending a message via the phone was chosen by only $5.6 \%$ of the participants. Interesting also is the fact that $12.2 \%$ of the participants would prefer other options, such as "going to the doctor" or "asking a pharmacist," but none of the choices involved using digital communication means.

"Asking for help" situations (in the case of chores and illness) is mostly associated by older persons with "calling family and friends" or meeting someone in person. Those who did not have family and friends in close proximity to help would have encountered serious difficulties during the COVID-19 lockdown. 


\section{Discussion}

The current study explores the digital opportunities and limitations older people from Romania would have encountered during the COVID-19 pandemic, especially in the context in which many everyday activities have been recommended to be performed online. We used the theoretical framework of the digital divide suggested by Van Dijk $(2006 ; 2012 ; 2020)$ and distinguished between the first level of the digital divide (access and use) and the second and third levels of the digital divide: types of use and the ability to convert digital skills to outcomes. We present data from a unique cross-national and longitudinal study on the new media use of older adults (60 years of age and older) already conducted in two waves (2016 and 2018). In the Romanian case, the initial sample consisted of older adults, it was representative at the national level, and we selected those who declared that they have access and use Internet at least once per week.

We asked in the beginning how digital inequalities shape the lives of older people in Romania. Our data support the idea that the digital divide reinforces classic inequalities by providing opportunities for users who are medium to highly educated, below 80 years of age, have above average economic resources, and live in urban areas. In contrast, the oldest-old populations who live in rural areas, and who have low levels of education are the most vulnerable because they lag in in digital use. Regarding the first research question, our analysis shows the fact that, when facing COVID pandemics, some older people could have found opportunities in their relatively diverse Internet behaviors, whereas others would have faced serious difficulties to go on with the daily life activities. Older adults, already skilled and more sophisticated in their online behaviors (usually younger, connected with the labor market, with medium to high socio-economic status, living in urban areas) probably would have found opportunities during pandemics to learn and acquire new digital skills. In contrast, for non-users and those with basic Internet skills (older, from rural areas, with lower education and economic status), the COVID pandemic would have accentuated the risks for social exclusion.

We presented the Romanian case as a typical case of what might happen with older adults in the context of a pandemic from the point of view of digital opportunities and limitations. We believe that similar situations could be found in other developing countries, and not only in Europe. Also, the case study presented here shows that although the first level of the digital divide is expected to diminish with the ubiquitous digital connectivity, some categories will experience risks of being left out of the benefits of the spread of technology. The situation of the oldest-old who have low levels of education and low incomes and who might be considered to be "digital immigrants" may be encountered in developed countries as well. Current policies that aim to reduce the digital divide no longer target access and use. 
Regarding the first research question and the opportunities or limitations older people could face in relation to their digital skills, we found evidence of the fact that the digital divide, at least insofar older persons are concerned, is a "moving concept." In a relatively short period of time (2016-2018), older people tended to diversify their Internet use by engaging in more activities. In particular, chat programs and websites for hobbies had the stronger ascendant dynamics. As Internet activities become more diverse, older people tend to spend less time doing each of them. It is worth exploring whether such Internet behavior is shared by other age categories. We lack comparative data on other age categories to conclude whether this is a universal pattern or specific to older adults.

Regarding the dynamics of people's skills, older people may become familiar and use some applications (as for example, taking photos or sending SMSs) in a relative short time (as here, between 2016-2018), whereas for other applications the percentage of users could remain rather low or constant over the same period of time. Further investigations will clarify older people's interests and the mechanisms by which they appropriate different digital functions. In previous studies (Nimrod \& Ivan, 2019; Ivan \& Hebblethwaite, 2016), when we have investigated patterns of use and motivations by interviewing older people from Romania, we found that taking photos and uploading and editing video materials were the skills most older people would like to acquire. When talking about improving digital skills of older adults, policy makers and developers should take into account what skills older people are motivated to acquire and what skills they might need in critical situations.

When trying to improve digital skills of older people, thus bridging the digital gaps between different age groups, we should not consider older people as a homogeneous group. We tend to represent them in a stereotypical way, as laggards. Still, older Internet users, as the current study also shows, are a group with relative heterogeneous digital skills and with decided preferences for using some of the digital functions.

\section{Limitations}

We are aware of the fact that the data presented here were collected prior to the COVID-19 pandemic and therefore our arguments regarding opportunities and limitations older people might have faced during the lockdown are rather speculative and seriously limit the current study. However, we conducted a series of interviews with older people during the lockdown period in Romania (March-April, 2020) and the preliminary findings (Ivan \& Mandache, submitted) suggest that older people did not diversify their online behaviors during the pandemics, but only intensified their already existing skills. Also, the ACT longitudinal study has just finished the data collection for the third wave (November-December, 2020), and we will be able to analyze the potential changes in the Internet behavior of our sample as compared to the second wave (prior to the COVID-19 pandemic). 


\section{Further developments}

Currently, the digital divide is discussed more in relation to people's abilities to convert skills to outputs in various domains from daily interactions to public participation. In the current study, we explored older people's digital opportunities in connection with the COVID-19 pandemic and lockdown. We conclude that when it comes to "retrieve factual information about an issue," a large majority of older people who were using the Internet consulted Google, although "calling someone" was also a largely used alternative. However, when it comes to asking for help in the case of chores and illness, "calling family and friends" or meeting people were the preferred ways of acting. It will be interesting to discover if these behaviors change after the COVID-19 lockdown ends. In fact, data collection for the third wave of the ACT longitudinal study is scheduled for November - December 2020, and it will capture potential changes in how older adults use the Internet and how their media preferences may have changed during this period of time.

Nevertheless, the current study draws attention to some aspects that need to be improved in the future if we aim to understand older people's digital behavior and needs. We lack the data to understand digital preferences of older people, particularly the oldest-old. We agree with Maria Sourbati (2019) that older people-non-users, people over 74 , and particularly people over 80 - are simply invisible in data regarding public policies. We have encountered diffi- culties in obtaining data at the national level from the National Institute of Statistics regarding the classic socio-demographic variables for the older population (60 years of age and older). Even when other sources were consulted, as for example the Eurostat data base, it was difficult to retrieve data about people older than 74 years. In addition, data regarding people 80 years and above, including their online behavior are scarce. We urge that there be greater data inclusiveness and share the point of view formulated in the new Manifesto for Digital Inclusion (Micklethwaite, 2020) - the need to bridge the different digital gaps and to create digital inclusiveness is connected to having more reliable data about digital behaviors of older people, especially about those being most at risk of exclusion.

\section{Policy recommendations}

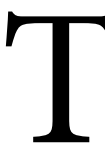

The analysis presented here suggests the fact that differences in the digital skills are a source of inequalities between different categories of older users and lie at the intersection of the classic inequalities with socio-economic and residential status as key factors. The article illustrates that it is not necessarily a matter of age, but a matter of opportunity to develop a digital sophistication which is more and more required in societies nowadays. Consequently, we suggest some policy recommendations which we believe do not apply only to the Romanian context

First, the role of community centers where older people could gather after retirement and acquire new digital 
skills could be accentuated. Such centers were mostly active in large urban settings, whereas the need for community gathering places is higher in isolated rural areas. The COVID-19 pandemic almost closed the few existing community centers, as they were not digitalized, leaving older adults outside of the community support.

Second, our previous studies with involving older adults revealed the importance of university courses for older adults, short-term courses, and courses addressing digital skills that older people might need in daily life. There is only one university in Romania offering courses for older adults, with no focus on digital literacy in particular. Still such examples, presented rather as exceptions, could attract more attention from policy makers, at least after the experience we had with the COVID-19 pandemic.

Nevertheless, policy makers should address categories of older people facing higher risks of social exclu- sion and initiate interventions in small communities and in rural settings, with a focus on the specific needs of such communities. Instead of aiming to improve the general digital skills of older adults, policy makes should aim to increase older people's digital skills in aspects which are relevant for their community life-as, for example, trading products, keeping in touch with families, participating to community events, and so on.

\section{Acknowledgements}

Data presented in the current article were collected as part of the project Ageing + Communication + Technologies (ACT), funded by the Social Sciences and Humanities Research Council of Canada (SSHRC) under grant agreement No. 895-2013-1018. The National University of Political Studies and Public Administration in Romania also provided funding and resources for the project.

\section{References}

Barrantes, R. (2007). Analysis of ICT demand: What is digital poverty and how to measure it? In H. Galperin \& J. Mariscal (Eds.), Digital Poverty: Latin American and Caribbean Perspectives (pp. 29-53). International Development Research Center: Practical Action.

Barrantes, R. \& Matos, P. (2020). Who benefits from open models? The role of ICT access. In M.L. Smith \& R.K. Seward (Eds.), Making Open Development Inclusive (pp. 219-248). International Development Research Center: MIT Press.

Brashier, N. M. \& Schacter, D. L. (2020). Aging in an era of fake news. Current Directions in Psychological Science, 28, 306-313. doi.org/10.1177/2F0963721 420915872. 
Bunker-Hellmich, L. A. (2015). The Demographics of an Aging Population. Retrieved 8 January 2021 from www.healthdesign.org/insights-solutions/de mographics-aging-population.

Ducu, V. (2020). Displaying grand parenting within Romanian transnational families. Global Networks, 20(2), 380-395. doi.org/10.1111/glob.12255.

European Commission (May, 2020). Covid-19 Cases and Case Fatality Rate by Age. Retrieved 19 September 2020 from: ec.europa.eu/knowledge4policy/pub lication/covid-19-cases-case-fatality-rate-age_en.

Eurostat (2019). Digital economy and society statistics - households and individuals. Retrieved 19 September, 2020 from: ec.europa.eu/eurostat/statisticsex plained/index.php?title=Digital_economy_and_society_statistics

Fernández-Ardèvol, M. (2011). Interactions with and through mobile phones: what about the elderly population. Wi: Journal of Mobile Media. Retrieved 26 April. 2020 from: wi.mobilities.ca.

Hargittai, E. (2002). Second-level digital divide: Differences in people's online skills. First Monday,7(4). doi.org/10.5210/fm.v7i4.942.

INS (Romanian National Institute of Statistics, 2017). Proiectarea populatiei Romaniei in profil teritorial la orizontul anului 2060 (Romanian Population Prospects for 2060). Retrieved 26 April 2020 from: insse.ro/cms/sites/default/files/field/publicatii/proiectarea_populatiei_romaniei_in_profil_teritorial_la_orizontul_2060.pdf

INS (Romanian National Institute of Statistics, 2016). Populatia Romaniei, pe localitati, la 1 ianuarie 2016 (Romanian Population at $1^{\text {st }}$ January, 2016). Retrieved 26 April 2020 from: insse.ro/

ITU (International Telecommunication Union, 2019). Measuring Digital Development. Facts and Figures 2019. Retrieved 26, 2020 from: www.itu.int/en/ ITU-D/Statistics/Documents/facts/FactsFigures2019.pdf

Ivan, L. \& Mandache, L. (submitted). Information sources and digital opportunities: older people during the COVID-pandemics lockdown in Romania.

Ivan, L. \& Fernández-Ardèvol, M. (2017). Older people and the use of ICTs to communicate with children and grandchildren. Transnational Social Review, 7(1), 41-55. doi.org/10.1080/21931674.2016.1277861.

Ivan, L. \& Hebblethwaite, S. (2016). Grannies on the net: Grandmothers' experiences of Facebook in family communication. Romanian Journal of Communication and Public Relations, 18(1), 11-25.

Jones, C. (2010). A new generation of learners? The net-generation and digital 
natives. Learning, Media and Technology, 35(4), 365-368. doi.org/10.1080/ 17439884.2010.531278

Juvonen, J. \& Gross, E. F. (2008). Extending the school grounds? Bullying experiences in cyberspace. Journal of School Health, 78(9), 496-505. doi.org/ 10.1111/j.1746-1561.2008.00335.x

Lenhart, A. \& Horrigan, J. B. (2003). Re-visualizing the digital divide as a digital spectrum. IT \& Society, 1(5), 23-39.

Loos, E. (2012). Senior citizens: Digital immigrants in their own country? Observatorio $\left(O B S^{*}\right), 6(1), 1-23$.

Loos, E., Ivan, L., \& Bird, I. (2020). The impact of technology generations on older adults' media use: Review of previous empirical research and a sevencountry comparison. Gerontechnology, 19(4), 1-doi.org/10.4017/gt.2020. 19.04.387

Loos, E., Nimrod, G., \& Fernández-Ardèvol, M. (Coords.). (2020). Older audiences in the digital media environment: A cross-national longitudinal study. Wave 2. Report v1.0. Montreal, Canada: ACT project. Retrieved 26 April 2020 from: spectrum.library.concordia.ca/986444/

Loos, E., Nimrod, G., \& Fernández-Ardèvol, M. (Coords.). (2018). Older audiences in the digital media environment: A cross-national longitudinal study. Wave 1 Report 1.0. Montreal, Canada: ACT project. Retrieved 26 April 2020 from: spectrum.library.concordia.ca/983866/

Loos, E., Ivan, L., \& Leu, D. (2018). "Save the Pacific Northwest tree octopus:" A hoax revisited. Information and Learning Science, 19(9/10), 514-528. doi. org/10.1108/ILS-04-2018-0031.

Micklethwaite, A. (2020). A New Manifesto for Digital Inclusion. Retrieved 9 September 2020 from: digitalagenda.io/insight/a-new-manifesto-for-digitalinclusion/

Morales, J. M. R., Albero, C.T., \& Molina, Ó. M. (2010). La brecha digital. Un análisis de las desigualdades tecnológicas en España. Revista de Ciencias Sociale, 218, 3-22.

Nimrod, G. (2017). Older audiences in the digital media environment. Information, Communication \& Society, 20(2), 233-249.

Nimrod, G. \& Ivan, L. (2019). The dual roles technology plays in leisure: Insights from a study of grandmothers. Leisure Sciences, 1-18. doi.org/10.1080/014 90400.2019.1656123

Pew Research Center (2019a). Digital Divide. Retrieved 19 September 2020 from: 
www.pewresearch.org/fact-tank/2019/05/07/

Pew Research Center (2019b). Internet and Technology. Internet/Broadband Fact Sheet. Retrieved 4 June 2020 from: https://www.pewresearch.org/internet/ fact-sheet/internet-broadband/

Prensky, M. (2001). “Digital Natives, Digital Immigrants Part 1.” On the Horizon, 9(5),1-6. doi.org/10.1108/10748120110424816.

Sackmann, R. \& Winkler, O. (2013). Technology generations revisited: The Internet generation. Gerontechnology, 11(4), 493-503. doi.org/10.4017/gt.20 13.11.4.002.00

Sawchuk, K., Joy, M., \& Hebblethwaite, S. (May, 2019). Opinion: The age-friendly city is everyone's responsibility. Montreal Gazzette. Retrieved 19 September 2020 from: montrealgazette.com/opinion/opinion-the-age-friendly-cityis-everyones-responsibility

Schiau, I., Ivan, L., \& Bîră, M. (2018). Involving older people in participatory action research: An example of participatory action design. Romanian Journal of Communication and Public Relations, 20(1), 11-24.

Selwyn, N. (2004). Reconsidering political and popular understandings of the digital divide. New Media \&Society, 6(3), 341-362. doi. 10.1177/1461444804042519

Shao, J., Zhang, Q., Ren, Y., Li, X., \& Lin, T. (2019). Why are older adults victims of fraud? Current knowledge and prospects regarding older adults' vulnerability to fraud. Journal of elder abuse \& neglect, 31(3), 225-243. doi.org/10. $1080 / 08946566.2019 .1625842$

Sourbati, M. (2018). Ageism, Social Inclusion and Digital Public Service: Considering Age Relations in the 21st Century. In E. Scabini \& G. Rossi (Eds.), Living Longer: A Resource for the Family, an Opportunity for Society (pp. 141-153). Common Ground Research Networks: University of Illinois, Campaign, IL.

UN (2019). United Nations World Population Prospects. Retrieved 4 June 2020 from: population.un.org/wpp/

Van Deursen, A. V. \& Van Dijk, J. A. (2014). The digital divide shifts to differences in usage. New Media \& Society, 16(3), 507-526. doi.org/10.1177\%2F1461 444813487959

Van Deursen, A. V. \& Van Dijk, J. A. (2010). Measuring Internet skills. International Journal of Human-Computer Interaction, 26(10), 891-91doi.org/10.1080 /10447318.2010.496338

Van Dijk, J. A. (2020). The Digital Divide. Cambridge: Polity Press. 
Van Dijk, J. A. (2012). The evolution of the digital divide: The digital divide turns to inequality of skills and usage. In J. Bus, M. Crompton, M. Hildebrandt, \& G. Metakides (Eds.), Digital Enlightenment Yearbook (pp. 57-75) Amsterdam: IOS Press. ebooks.iospress.nl/publication/31966. doi.10.3233/978-161499-057-4-57

Van Dijk, J. A. (2006). Digital divide research, achievements, and shortcomings. Poetics, 34(45), 221-235. doi.org/10.1016/j.poetic.2006.05.004.

Van Dijk, J. A. (2005). The Deepening Divide: Inequality in the Information Society. London: Sage.

Van Dijk, J. A. \& Hacker, K. (2003). The digital divide as a complex and dynamic phenomenon. The Information Society, 19(4), 315-326. doi/abs/10.1080/ 01972240309487.

Whitty, M. T. (2018). Do you love me? Psychological characteristics of romance scam victims. Cyberpsychology, Behavior, and Social Networking, 21(2), 105-109.doi.org/10.1089/cyber.2016.0729 